\title{
Kimya Endüstrilerinde Patlama ve Yangınların Önlenmesi ve İlgili Vaka Çalışması
}

\author{
Prevention of Explosion and Fire in Chemical Industries and A Related Case Study
}

\author{
Ufuk MEVLEVIOĞLLU1 ${ }^{\circledR}$, M.A. Neşet KADIRGAN ${ }^{1}$, Gökçen Alev ÇİFTÇİOĞLU1 ${ }^{1}$ \\ ${ }^{1}$ Marmara Üniversitesi, Kimya Mühendisliği Bölümü, 34722, Ístanbul, Türkiye
}

Öz

Bu çalışmada, iş yerlerinde karşılaşılabilen patlama ve yangın risklerini değerlendirmek ve bu risklere karşı alınabilecek önlemleri belirlemek için Türkiye'nin ulusal mevzuatı ve TSE standartlarında belirtilen yöntemler incelenmekte ve hayali bir kimya tesisine uygulanmaktadır. Hayali tesisteki solvent tankı ve solvent pompası için yapılan değerlendirmede, tank içerisinin "Bölge 0" patlayıcı ortam olarak sınıflandırılabileceği, pompa etrafında ise çeşitli mühendislik yaklaşımlarıyla farklı patlayıcı ortam değerlendirmeleri yapılabileceği sonuçlarına varılmıştır. Ayrıca hayali tesisteki polimer toz besleme hunisi için yapılan değerlendirmede, huni içerisinin "Bölge 20" patlayıcı ortam olarak sınıflandırılabileceği, huni etrafında oluşabilecek patlayıcı ortamın tehlike mesafesinin ise, ilgili standartta verilen nitel yöntemlere dayanarak tahmini olarak yapılabileceği gösterilmiştir. Sınıflandırılmış olan bu tehlikeli bölgelerin dahilinde kullanılabilecek cihazların kategorileri ve diğer özellikleri belirlenmiş, bu bölgelerde patlama ve yangınlara karşı alınabilecek önlemlere çeşitli örnekler verilmiştir. Sonuç olarak kimya endüstrisinde sıkça rastlanabilecek tanklar, pompalar, solventler vb. etkenlerle ilgili deneysel veriler üretilmesine ve yanıcı tozlarla ilgili standart testleri yapabilecek akredite laboratuvarlara ihtiyaç duyulduğu vurgulanmıştır.

Anahtar Kelimeler: tehlikeli bölge sınıflandırma, yangın ve patlamadan korunma, patlayıcı ortam hesaplamaları

\begin{abstract}
This study introduces the assessment and prevention methods of explosion and fire risks in workplaces stated in Turkey's national legislation and TSE standards, then will be applied into a fictive chemical facility. In the assessment of the solvent tank and solvent pump of this fictive facility, it has been concluded that inside of the tank can be classified as Zone 0 explosive atmosphere and various explosive atmosphere assessments can be made around the pump with various engineering approaches. It has also been shown that as a result of the assessment of the polymer dust feed hopper, hopper interior can be classified as Zone 20 explosive atmosphere and the distance of the explosive atmosphere that can occur around the hopper can be predicted based on qualitative methods given in the relevant standard. The categories and other characteristics of the equipment that can be used within these classified hazardous areas have been identified, and precautions that can be taken against explosion and fire risks in these areas have been summarized. As a result, it was emphasized that accredited laboratories for carrying out standard tests on combustible powders and experimental data for tanks, pumps, solvents etc. which are frequently encountered in the chemical industry are needed.
\end{abstract}

Keywords: zone classification, fire and explosion protection, explosive atmosphere calculations

\section{I.GÍRIŞ}

Yanıcı kimyasal maddelerin gaz, buhar, sis ve tozlarının hava ile oluşturduğu ve tutuşması halinde tümüyle yanabilen karışımlar "patlayıcı ortam” olarak tanımlanmakta olup boya/baskı, petrokimya, deri, tekstil, ilaç ve diğer kimya endüstrilerinde çalışanlar ve işyeri güvenliği açısından önemli bir tehlike kaynağı oluşturmaktadır [1]. Kimyasal gaz ve toz patlamaları sonucunda can ve mal kayıpları meydana gelmekte, çalışanlar ve ekipmanlar önemli zararlar görmektedir. Patlayıcı ortam oluşabilecek tüm yerlerde risk değerlendirmesi yapılmalı, sonuçlara göre gerekli ve mümkün olan tüm teknik ve organizasyonel önlemler belirlenerek uygun ekipman ve koruyucu sistemler seçilmelidir [1]. 
$\mathrm{Bu}$ çalışmanın kapsamında; yanıcı gazların, sıvı buharlarının, sislerin veya tozların atmosferdeki oksijenle karıştı̆̆ında oluşturabileceği patlayıcı ortamlar detaylı olarak incelenecektir. Atmosferik oksijene ihtiyaç duymadan kendi kendine oksitlenerek patlayabilen maddeler ve yalnızca basınçtan kaynaklanan fiziksel patlamalar çalışmanın kapsamı dışında tutulacaktır. Aksi taktirde çalışmanın kapsamı fazla geniş bir hale gelebileceğinden, bu şekilde sınırlandırılmıştır.

Türkiye'de, bu konuda Avrupa mevzuatı ve standartlarına uyumlu olarak oluşturulmuş ulusal mevzuat ve standartlar uygulanmaktadır. Bu mevzuat ve standartlara uygun olarak yapılan çalışmalarda, tesislerdeki tüm bölümler, makineler, prosesler ve maddeler ile bunların karşılıklı etkileşimleri incelenerek patlayıcı ortamların oluşması, bu ortamın tutuşturucu kaynaklarla buluşması ihtimali ve olası patlamanın şiddeti değerlendirilir [2]. Değerlendirme yapılırken planlı faaliyetlerde ortama salınan yanıcı maddelerin yanı sıra, olası kazalar veya hata durumlarında oluşabilecek yanıcı madde salımları da göz önüne alınmalıdır. Değerlendirmede ortama yayılan/salınan yanıcı maddenin fiziksel ve kimyasal özellikleri, debisi, sıcaklı̆̆ı, basıncı, kısıtlanmışlığı, salım sıklığı ve daha birçok koşul göz önünde bulundurularak patlayıcı atmosfer sinıflandırması yapılır ve buna bağlı olarak ortamdaki elektrikli veya tahrikli cihazların uygunlukları değerlendirilerek olası tutuşturma kaynakları denetlenir. Bu değerlendirme sonucunda tesislerdeki tüm patlayıcı ortamların oluşma ve tutuşma riskleri kontrol altına alınmaya çalışı1ır. Eğer patlamanın gerçekleşmesi olasılı̆̆ 1 yeterince düşürülemezse, gerçekleşmesi halinde oluşabilecek zararların boyutu da incelenmeli, bu patlamaların yıkım etkilerini söndürmek, azaltmak veya bertaraf etmek için teknik ve organizasyonel önlemler de belirlenerek uygulanmalidır.

Bu çalışmada, Türkiye'deki kimya endüstrisine, patlama ve yangından korunmak üzere ulusal ve Avrupa mevzuatı ve standartlarına uygun çalışmaları yapabilmesi için bir kaynak oluşturmak amaçlanmıştır.

\section{II.MATERYAL ve YÖNTEM}

\subsection{Yangın ve Patlamanın Kimyası}

Yangın; sonucunda 1sı, 1şık ve diğer çeşitli yanma ürünlerinin oluştuğu, ekzotermik ve hızlı bir oksidasyon reaksiyonudur. Bir yangının oluşması için bir araya gelmesi gereken 3 ana etken; yakıt, oksitleyici ve tutuşma olarak bilinir. 3 ana unsurdan biri devre dışı edilebilirse yangın tehlikesi ortadan kalkar.

$$
\mathrm{C}_{\mathrm{x}} \mathrm{H}_{\mathrm{y}}+(\mathrm{x}+\mathrm{y} / 4) \mathrm{O}_{2}-\longrightarrow \mathrm{xCO}_{2}+(\mathrm{y} / 2) \mathrm{H}_{2} \mathrm{O}
$$

Patlama ise; oksijen ile yanıcı maddenin belli bir orandaki karışımının tutuşturma kaynağı ile buluşması sonucunda, yanıcı maddenin tamamının veya büyük bir kısmının hızla yanması sonucunda bir şok dalgası oluşturan kimyasal reaksiyon olarak tanımlanır. Yangın ve patlama olaylarında gerçekleşen kimyasal reaksiyon aynıdır, ancak patlama olayında reaksiyonun yanıcı madde kütlesindeki ilerleme hızı çok büyüktür ve bu nedenle bir şok dalgası oluşmaktadır. Reaksiyondaki bu yüksek ilerleme hızı, yangın ana etkenlerine ek olarak yakıt ile oksijenin birbiri içerisinde dağılmış olmasını (karışma) ve ortamdaki yakıt miktarının, belli bir konsantrasyon aralığında olmasını gerektirir. Bu konsantrasyon aralığının alt eşiği "Alt Patlama (veya Alevlenme) Limiti”, üst eşiği ise "Üst Patlama (Alevlenme) Limiti”" olarak adlandırılmış olup bu değerler, kimyasala özgü karakteristiktir. Örneğin, alt ve üst patlama limitleri sırasıyla Benzenin $\% 1,2$ - \%8,6 ; Metanın \%4,4 - \%17 ; Asetilenin \%2,3 - 100'dür [3]. 5 ana unsurdan biri devre dişı edilebilirse patlama tehlikesi ortadan kalkar.

Parlama noktası, proses/ortam sıcaklığından yüksek olan sıvılar, ortama tutuşabilecek kadar buhar çıkarmayacağından patlama riski taşımaz. Ancak parlama noktası, proses/ ortam sıcaklığından düşük olan sıvılar, tutuşabilecek miktarda buhar çıkaracağından çok ciddi yangın riski taşımakla birlikte, oluşan buhar ortamda birikirse patlama riski de taşır. Bu süreç doğal olarak sıvının sıcaklığından güçlü bir şekilde etkilenir.

Toz veya elyaf halindeki yanıcı katı maddeler, havada bulut halinde dağılabilecek yapıda ise atmosferik oksijen ile tepki verip patlayabilirler. Yanıcı tozun tanecik çapı yaklaşık olarak ortalama $0,5 \mathrm{~mm}$ 'den küçükse patlama riski olabilir, büyükse patlaması beklenmez ancak eğer elyaf şeklinde ipliksi yapıda olan bazı katı parçacıklar, $0,5 \mathrm{~mm}$ çapından büyük boyutta olsalar bile patlayıcı ortam oluşturabilirler. Tanecik çapı ne kadar küçükse, havada asılı kalıp dağılabilme kabiliyeti ve dolayısıyla patlama potansiyeli o kadar yüksek olur. Genel olarak bir toz patlamasına sebep olabilecek minimum toz konsantrasyonu 30-60 g/ $\mathrm{m}^{3}$, maksimum toz konsantrasyonu ise $2-4 \mathrm{~kg} / \mathrm{m}^{3}$ 'tür. Bu sinırlar, yanıcı tozun cinsine ve tanecik büyüklüğü dağıllımına bağlı olarak değişebilir. Toz tabakaları, tutuşması halinde için için yanmaya duyarlıdır; havada asılı bir toz bulutu ise tutuşması halinde patlayabilir. Birikmiş toz tabakaları tutuşup, kendisi bir tutuşturma kaynağı görevi görerek daha büyük patlamalara sebebiyet verebilir. Ayrıca bir gaz, buhar ya da toz patlaması, patlamanın olduğu mekânda ki başka tozları kaldırabilir ve ilk patlama, ikincil ve daha da tehlikeli bir toz patlamasına dönüşebilir [4].

Yanıcı maddelerin veya patlayıcı ortamların yanma reaksiyonunu başlatabilecek çok çeşitli tutuşturma kaynakları mevcuttur. Açık alev, mekanik etkilerle oluşan kıvılcımlar, 
elektrikli aparatlar, yıldırım, statik elektrik ve ekzotermik reaksiyonlara kimya endüstrisinde sıkça rastlamak mümkündür. Risk değerlendirmesi yapılırken ve gerekli önlemler belirlenirken, tutuşturma kaynaklarının tümü göz önüne alınarak mümkün olduğunca tehlikeli bölgelerden uzaklaştırılmalıdır [1].

Elektrikli ekipmanlar, düşük voltajlarda bile patlayıcı ortamları tutuşturabilecek enerjiye sahip sıcak yüzeyler veya elektriksel kıvılcımlar oluşturabilir. Ayrıca elektrikli olmasa bile hava veya başka tahriklerle çalışan ekipmanların döner aksamları, olası arıza hallerinde mekanik kıvılcımlar veya yüksek 1s1 oluşturabilir, hatta çelikten üretilmiş çekiç vb. el aletleri çarpma veya sürtünme sonucu tutuşmaya sebep olabilir $[2,5]$. İletken olmayan malzemelerden yapılan (Ör: polimer) filmler makaralarda döndürülürken, özellikle iletkenliği düşük olan sıvılar borularda aktarılırken veya tanklarda karıştırılırken, toz veya granül haldeki katılar kovalardan boşaltılırken, insanlar günlük işlerini yaparken veya başka çok çeşitli şekillerde statik elektrik oluşabilir.

\subsection{Patlama ve Yangından Korunma}

Patlamaların önlenmesi ve patlamalardan korunma amacıyla teknik ve organizasyona yönelik önlemler alınırken aşağıda belirtilen temel ilkelere ve verilen öncelik sirasina uyulur [1];

\section{a) Patlayıcı ortam oluşmasısını önlemek}

Yanıcı maddelerin kullanımından kaçınarak veya azaltarak tehlikeli patlayıcı ortamların oluşması önlenebilir [2]. Tozlarla ilgili olarak, parçacık büyüklüğünü arttırmak bazen mümkündür, böylece katı parçacıklar havada asılı kalmayarak zemine/yüzeylere çöker ve patlayıcı bir karışım oluşmaz. Yanıcı madde salımını kısıtlayarak veya ortamdaki havalandırmanın etkisini artırarak alt patlama sınırının altında kalmak mümkün olabilir [2]. Endüstriyel uygulamalarda genel olarak, alt patlama limitinin \%20'sinden düşük konsantrasyonlar güvenli kabul edilir. Doğal havalandırma, toz birikimi olabilen yerlerde biriken tozları havaya savurarak patlayıcı atmosfer oluşmasına sebep olabilmektedir. Bununla beraber cebri-lokal havalandırma ile direkt salım kaynağından tozun çekilmesi ile tehlikeli bölgeyi küçültmek/ yok etmek mümkün olabilmektedir. İnert gazların (azot, karbon dioksit, soy gazlar vb.), su buharının veya işlenen ürünlerle uyumlu, inert toz halindeki maddelerin (kalsiyum karbonat vb.) ilave edilmesi, patlayıcı ortamların oluşmasını önleyebilir (inertleştirme) [2].

\section{b) Yapılan işlemlerin doğası gereği patlayıcı ortam oluşmasının önlenmesi mümkün değilse, patlayıcı ortamın tutuşmasını önlemek}

Kaynak, taşlama vb. sıcak işler ya da sigaradan kaynaklı alevler veya kıvılcımlar, organizasyon önlemleri ile engellenmelidir. Bunun için dünya çapında yaygın olarak "çalışma izni sistemleri" kullanılmaktadır. Çalışma izni sistemlerinde, sıcak işler ve özel risk kaynağı olan diğer tüm faaliyetler, ancak bölüm yöneticileri ve iş güvenliği sorumlularından alınacak özel izin ve imzalı bir form aracılığıyla yapılabilmektedir. Böylece riskli faaliyetin güvenli bir şekilde gerçekleştirilebilmesi için gaz ölçümü, yanıcı maddelerin ve tutuşturma kaynaklarının ortamdan uzaklaştırılmış olması, kullanılacak ekipmanın işe uygunluğu, işi yapacak personelin eğitiminin uygunluğu, acil durum müdahale planı vb. gerekli tüm önlemlerin alındığından emin olunması amaçlanmaktadır.

Tehlikeli bölgelerde statik elektriğin oluşmasını kısıtlayacak veya iletkenlik sağlayarak birikmeden boşalmasını sağlayacak tasarım ve malzeme seçimi yapılmalı, iletken olan tüm ekipmanlar topraklanmalıdır [2]. İletken veya anti-statik zemin kaplamaları, anti-statik ayakkabı ve iş kıyafetleri gibi önlemler de alınabilir. Ayrıca havanın bağıl neminin $\% 65$ 'in üzerinde tutulması, aslında yalıtkan olan malzemelerin çoğunluğunun yüzeyinde yeterince nem adsorblanarak iletken hale gelmesini ve dolayısıyla statik elektriğin hava yoluyla boşalmasını sağlar [6].

Tehlikeli bölgelerde bakır-berilyum, alüminyum-bronz vb. özel alaşımlardan, özel ısıl işlemlerle üretilmiş kıvılcım çıarmayan el aletleri kullanılmalıdır.

Tehlikeli bölgelerde kullanılacak elektrikli ekipmanlar veya tahrikli cihazlar ise; patlamaya karşı korunmuş tip (Exproof) olmalı ve tehlikeli bölge sınıfının ve yanıcı maddenin gerektirdiği özelliklere uygun olmalıdır. Bölge sınıfına bağlı olarak ekipmanın hangi kategoriye sahip olması gerektiği, Tablo.1'de listelenmiştir. Ekipman üreticileri, ürettikleri ekipmanların kategorilerini ve diğer özellikleri, akredite/ onaylanmış kuruluşlar aracılı̆̆ıyla, "EU-Type Examination Certificate" (endüstride "ATEX sertifikası" olarak bilinir) belgeleri edinerek kanitlamalıdır [5, 7].

Tablo 1. Tehlikeli bölgelerde kullanılacak teçhizatın ATEX ekipman kategorileri [7]

\begin{tabular}{|l|l|l|}
\hline Bölge Sınıfı & Ekipman Kategorileri & ....... İçin Tasarlanmış İse \\
\hline 0 & II 1 G & \multirow{2}{*}{ Gaz, buhar veya sis ile hava } \\
karışımı
\end{tabular}


Tehlikeli bölgelerde kullanılacak elektrikli veya tahrikli ekipmanların yüzeylerinin ulaşabileceği en yüksek sıcaklık değeri, ortamda bulunabilecek yanıcı maddenin tutuşma sıcaklığından düşük olmalıdır $[8,9]$. Ekipmanlar, yüzeyinin ulaşabileceği en yüksek sıcaklık değerine göre Tablo.2'deki gibi sınıflandırılır. En yüksek yüzey sıcaklığı, tablodaki iki sınır değerin arasına denk gelen ekipmanlar, bu iki sınır değerden üsttekinin sıcaklık sınıfına atanır.

Gaz ve buharlar ayrıca, tutuşma hassasiyetlerine bağlı olarak 3 gruba (IIA, IIB, IIC) ayrılırlar. IIA'dan IIC'ye doğru gittikçe minimum tutuşma akımı (veya enerjisi) düşer. Minimum tutuşma akımı, IEC 60079-11 standardına göre kıvılcım deneyi donanımındaki patlayıcı deney karışımının tutuşmasına sebep olan rezistif veya endüktif devrelerdeki en küçük akım olarak tanımlanır [3].

Tablo 2. Tehlikeli bölgelerde kullanılacak teçhizatın sıcaklık siniflar1 [8]

\begin{tabular}{|l|l|}
\hline Sıcaklık Sınıfı & En Yüksek Yüzey Sıcaklığı $\left({ }^{\circ} \mathbf{C}\right)$ \\
\hline T1 & 450 \\
\hline T2 & 300 \\
\hline T3 & 200 \\
\hline T4 & 135 \\
\hline T5 & 100 \\
\hline T6 & 85 \\
\hline
\end{tabular}

c) Çalışanların sağlık ve güvenliklerini sağlayacak şekilde patlamanın zararlı etkilerini azaltacak önlemleri almak.

Çoğu gaz/hava ve toz/hava karışımı için en yüksek patlama basınc1 8-10 bardır, ancak alüminyum veya magnezyum gibi hafif metallerin tozları için daha yüksek olabilir. Tank, boru ve kap gibi tesis öğeleri, içten patlamalarda beklenen en yüksek basınca dayanıklı inşa edilmelidir. Özellikle tanklarda, olası en yüksek patlama basıncına dayanamayabileceği durumlarda, patlamanın en güvenli (insanlardan ve kritik ekipman kontrol bölgelerinden uzak) bölgeye doğru yönlenmesi sağlanabilir [10]. Bunun için tankın uygun bir yönü, bilinçli olarak zayıf tasarlanarak patlama basıncının bu yönden tankı yırtarak nispeten güvenli olan kısma doğru boşalması sağlanır, böylece diğer bölümlerdeki insan ve ekipmanlar korunmuş olur.

Patlama, sensörler tarafindan algılanarak çok kısa bir tepki süresinde ekipman içine yangın söndürme maddesi enjekte edilip alev bastırılabilir. Bu sistemlerin tasarımında, patlama basıncının artış hızı $(\mathrm{dP} / \mathrm{dt})$ çok önemlidir. Tüm yanıcı maddeler için bu değer karakteristiktir ve standart testlerle tespit edilebilir $[10,11]$.
Bir boru boyunca hareket eden bir patlama, sensörler tarafından algılanarak milisaniyeler içinde bir vana veya kapağı kapatarak patlamanın ilerleyişi durdurulabilir [10].

İçinden yanıcı madde geçen aktarım hattına, gözenekli/ hücresel filtre benzeri bir teçhizat eklenebilir. Bu teçhizat alevin hızını düşürerek kendi yanma ürünleri içerisinde boğulmasını ve sönmesini sağlar. Bu teçhizat patlama basıncının yönlendirildiği sistemlere entegre edilerek alevsiz bir basınç boşalması da sağlanabilmektedir. Böylece iç ortamlarda, yangınlara sebep olmadan basınç yönlendirme sistemleri kurulabilmektedir [10].

\subsection{Yöntem}

Tehlikeli bölge sınıflandırması ve bu bölgelerde kullanılacak teçhizatın seçimi için Türkiye'de iş yerlerini düzenleyen temel mevzuatlar olarak "Çalışanların Patlayıcı Ortamların Tehlikelerinden Korunması Hakkında Yönetmelik" ve "Muhtemel Patlayıcı Ortamda Kullanılan Teçhizat ve Koruyucu Sistemlerle İlgili Yönetmelik" geçerli olup, ayrıca birçok TS EN standardı (Ör: TS EN 60079 serisi, TS EN 13463-1 vb.) mevcuttur. Bu mevzuat ve standartlara göre patlama tehlikesi olan yerler, patlayıcı ortam oluşma sıklığı ve bu ortamın devam etme süresi esas alınarak, Tablo.3'deki gibi sınıflandırılmıştır [1].

Tablo 3. Tehlikeli bölge sınıfları [1]

\begin{tabular}{|l|l|}
\hline Bölge Sınıfı & Açıklama \\
\hline Bölge 0 & $\begin{array}{l}\text { Gaz, buhar ve sis halindeki yanıcı maddelerin hava ile ka- } \\
\text { rışımından oluşan patlayıcı ortamın sürekli olarak veya } \\
\text { uzun süreli ya da sık sık oluştuğu yerler. }\end{array}$ \\
\hline Bölge 1 & $\begin{array}{l}\text { Gaz, buhar ve sis halindeki yanıcı maddelerin hava ile ka- } \\
\text { rışımından oluşan patlayıcı ortamın normal çalışma ko- } \\
\text { şullarında ara sıra meydana gelme ihtimali olan yerler. }\end{array}$ \\
\hline Bölge 2 & $\begin{array}{l}\text { Gaz, buhar ve sis halindeki yanıcı maddelerin hava ile ka- } \\
\text { rışarak normal çalışma koşullarında patlayıcı ortam oluş- } \\
\text { turma ihtimali olmayan yerler ya da böyle bir ihtimal olsa } \\
\text { bile patlayıcı ortamın çok kısa bir süre için kalıcı olduğu } \\
\text { yerler. }\end{array}$ \\
\hline Bölge 20 & $\begin{array}{l}\text { Havada bulut halinde bulunan tutuşabilir tozların, sürekli } \\
\text { olarak veya uzum süreli ya da sık sık patlayıcı ortam oluş- } \\
\text { turabileceği yerler. }\end{array}$ \\
\hline Bölge 21 & $\begin{array}{l}\text { Normal çalışma şartlarında, havada bulut halinde bulunan } \\
\text { tutuşabilir tozların ara sıra patlayıcı ortam oluşturabile- } \\
\text { ceği yerler. }\end{array}$ \\
\hline Bölge 22 & $\begin{array}{l}\text { Normal çalışma şartlarında, havada bulut halinde bulu- } \\
\text { nan tutuşabilir tozların patlayıcı ortam oluşturma ihtimali } \\
\text { bulunmayan ancak böyle bir ihtimal olsa bile bunun yal- } \\
\text { nızca çok kısa bir süre için geçerli olduğu yerler. }\end{array}$ \\
\hline
\end{tabular}

Alevlenebilir maddelerin, patlayıcı ortam oluşabilecek şekilde ortama salınabildiği nokta veya konum, "salım 
kaynağı" olarak tanımlanmış olup, 3 salım derecesi belirlenmiştir [4, 12]:

Sürekli Salım: Sürekli olan veya uzun periyotlar boyunca veya sıklıkla olması beklenen salım.

Birincil Salım: Normal çalışma sırasında periyodik olarak veya nadiren olması beklenebilen salım.

İkincil Salım: Normal çalışmada olması beklenmeyen ve olursa yalnızca kısa bir periyot boyunca ve seyrek olarak meydana gelmesi muhtemel olan salım.

Sıvı, gaz veya buhar salımları sonucu oluşan tehlikeli bölge sınıflarını belirlemede ve salım kaynağı etrafındaki tehlike mesafelerinin hesaplanmasinda, TS EN 60079-10-1 standardındaki formüller yanıcı maddelerin salım hızını ve ortamdaki havalandırmanın etkinliğini tespit ederek değerlendirmek temelinde kuruludur. Vaka çalışmasında kullanacağımız formüller Tablo.4'de gösterilmiş, formüllerde kullanılan sembollerse Tablo.5'de açıklanmıştır.

Tablo 4. Hesaplamalarda kullanılacak formüller [12]

\begin{tabular}{|c|c|c|c|c|}
\hline No & $\begin{array}{l}\text { Sem- } \\
\text { bol }\end{array}$ & Açıklama & Formül & Birim \\
\hline 1 & W & $\begin{array}{l}\text { Sivının boru- } \\
\text { dan kaçak/sa- } \\
\text { lım hızı }\end{array}$ & $W=C_{d} S \sqrt{2 \rho \Delta p}$ & $\mathrm{~kg} / \mathrm{sn}$ \\
\hline 2 & $\mathrm{~W}$ & $\begin{array}{l}\text { Dökülmüş SIV1- } \\
\text { nın buharlaşma } \\
\text { hızı } \\
(1 \mathrm{~cm} \text { derin- }\end{array}$ & $W=\frac{6,55 u_{w}^{0,78} A_{p} p_{v} M^{0,667}}{}$ & $\mathrm{~g} / \mathrm{sn}$ \\
\hline 2 & $\Gamma_{\mathrm{e}}$ & $\begin{array}{l}\text { liğinde havuz } \\
\text { oluşturduğu } \\
\text { varsayılmıștır) }\end{array}$ & $W_{e}=\frac{R \times T}{R}$ & $g / s n$ \\
\hline 3 & $\rho_{g}$ & $\begin{array}{l}\text { Oluşan buharın } \\
\text { yoğunluğu }\end{array}$ & $\rho_{g}=\frac{p_{a} M}{R T_{a}}$ & $\mathrm{~kg} / \mathrm{m}^{3}$ \\
\hline \multirow[b]{2}{*}{4} & \multirow[b]{2}{*}{$\mathrm{K}$} & \multirow{2}{*}{$\begin{array}{l}\text { Salım karakte- } \\
\text { ristiği }\end{array}$} & $W_{g}$ & \multirow[b]{2}{*}{$\mathrm{m}^{3} / \mathrm{sn}$} \\
\hline & & & $\overline{\rho_{g} k L F L}$ & \\
\hline
\end{tabular}

Tablo 5. Formüllerde kullanılan semboller [12]

\begin{tabular}{|l|l|l|}
\hline $\begin{array}{l}\text { Sem- } \\
\text { bol }\end{array}$ & Açıklama & Birim \\
\hline $\mathrm{A}_{\mathrm{p}}$ & Havuz/birikintinin yüzey alanı & $\mathrm{m}^{2}$ \\
\hline $\mathrm{C}_{\mathrm{d}}$ & $\begin{array}{l}\text { Salım açıklıklarının ayırt edici bir özelliği olan ve he- } \\
\text { saplamaya türbülans ve viskozitenin etkilerini dahil } \\
\text { eden tahliye katsayısıdır. }\end{array}$ & $\begin{array}{l}\text { birim- } \\
\text { siz }\end{array}$ \\
\hline $\mathrm{M}$ & Gaz veya buharın mol kütlesi & $\begin{array}{l}\mathrm{kg} / \\
\mathrm{kmol}\end{array}$ \\
\hline$\Delta \mathrm{p}$ & Salımın gerçekleştiği açıklıktaki basınç fark1 & $\mathrm{Pa}$ \\
\hline $\mathrm{p}_{\mathrm{a}}$ & Atmosferik basınç (101.325) & $\mathrm{Pa}$ \\
\hline $\mathrm{p}_{\mathrm{v}}$ & T sıcaklığındaki sıvının buhar basıncı & $\mathrm{kPa}$ \\
\hline
\end{tabular}

\begin{tabular}{|l|l|l|}
\hline $\mathrm{R}$ & Evrensel gaz sabiti (8314) & $\begin{array}{l}\mathrm{J} / \mathrm{kmol} \\
\mathrm{K}\end{array}$ \\
\hline$\rho$ & Sivının yoğunluğu, özgül ağırlı & $\mathrm{kg} / \mathrm{m}^{3}$ \\
\hline$\rho_{\mathrm{g}}$ & Gaz veya buharın yoğunluğu & $\mathrm{kg} / \mathrm{m}^{3}$ \\
\hline $\mathrm{S}$ & Akışkanın salım yaptığı açıklığın (deliğin) kesiti & $\mathrm{m}^{2}$ \\
\hline $\mathrm{T}$ & Gaz veya sıvı akışkanın mutlak sıcaklığ1 & $\mathrm{K}$ \\
\hline $\mathrm{T}_{\mathrm{a}}$ & Mutlak ortam sıcaklığ1 & $\mathrm{K}$ \\
\hline $\mathrm{u}_{\mathrm{w}}$ & $\begin{array}{l}\text { Salım kaynağ1 yakınındaki veya sıvı havuzu yüzeyin- } \\
\text { deki rüzgar hızı }\end{array}$ & $\mathrm{m} / \mathrm{sn}$ \\
\hline $\mathrm{W}$ & Sıvının salım hızı & $\mathrm{kg} / \mathrm{sn}$ \\
\hline $\mathrm{W}_{\mathrm{e}}$ & Sıvının buharlaşma hızı & $\mathrm{kg} / \mathrm{sn}$ \\
\hline $\mathrm{W}_{\mathrm{g}}$ & Alevlenebilir gaz/buharın toplam kütlesel salım hızı & $\mathrm{kg} / \mathrm{sn}$ \\
\hline $\mathrm{k}$ & LFL ile ilgili bir emniyet katsayısı & $\begin{array}{l}\mathrm{birim}- \\
\mathrm{siz}\end{array}$ \\
\hline LFL & Alt alevlenme sınırı & $\begin{array}{l}\mathrm{hac} / \\
\mathrm{hac}\end{array}$ \\
\hline
\end{tabular}

Bu formülasyonlarla tespit edilen SK ve $u_{w}$ değerleri kullanılarak, Şekil.1'deki grafikten "seyrelme derecesi" tespit edilir.

Seyrelme derecesi; havalandırmanın, bir salımı güvenli bir seviyeye kadar seyreltme etkinliğinin ölçüsü olup, 3 seyrelme derecesi tanımlanmıştır [12]:

Yüksek seyrelme: Salım kaynağının yakınındaki derişim hızla azalır ve salım durduktan sonra neredeyse hiç kalıcıllı̆ı olmaz.

Orta seyrelme: Salım devam ederken kararlı bir bölge sınırı oluşturularak derişim kontrol altına alınır ve ayrıca sa1 ım durduktan sonra patlayıcı gaz ortamı aşırı derecede kalıc1lığını sürdürmez.

Düşük seyrelme: Salım devam ederken derişim büyüktür ve/veya salım durduktan sonra alevlenebilir ortamın kalıcıllğı büyüktür.

Daha sonra, Tablo.6 üzerinde salım derecesi, seyrelme derecesi ve havalandırmanın emre amadeliği (güvenilirliği) verileri kullanılarak tehlikeli bölgenin sınıfı belirlenir. Havalandırma için üç emre amadelik derecesi tanımlanmıştır [12]:

İyi: Havalandırma neredeyse sürekli mevcuttur.

Vasat: Havalandırmanın normal çalışmada sürekli mevcut olması beklenir. Ancak seyrek ve kısa süreli kesintiler olabilir.

Kötü: İyi veya orta emre amadelik derecesini karşılamayan havalandırmadır, fakat yine de kesintilerin uzun sürelerle oluşması beklenmez.

Sınıflandırılmış olan tehlikeli bölgenin mesafesini değerlendirmek içinse, yine SK değeri ve gaz/buharın salım tipi kullanılarak Şekil.2'deki grafikten "tehlikeli mesafe" tespit edilir. 3 salım tipi tanımlanmıştır [12]: 
Jet Tipi Salım: Bir boru bağlantı elemanındaki sızıntının, basıncın yüksek olması durumunda, yüksek hızda bir jet salım oluşturması beklenir. Jet kendi kendine seyrelecek ve hatta belirgin başka hava hareketi olmaksızın dağılacaktır.

Difüzyon Tipi Salım: Düşük hızda difüzyonla yayılan veya salım geometrisinden ya da yakın yüzeylere çarpmadan kaynaklı ivmesini kaybeden jet salımlardır.

Ağır Gaz Tipi Salım: Yatay yüzeyler (örneğin toprak) boyunca yayılan ağır gazlar veya buharlardır.

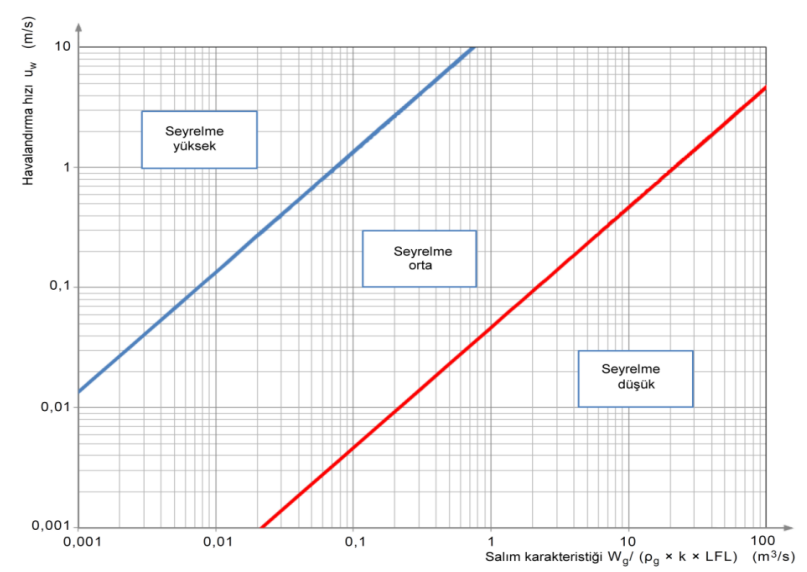

Şekil 1. Seyrelme derecesini değerlendirme grafiği [12]

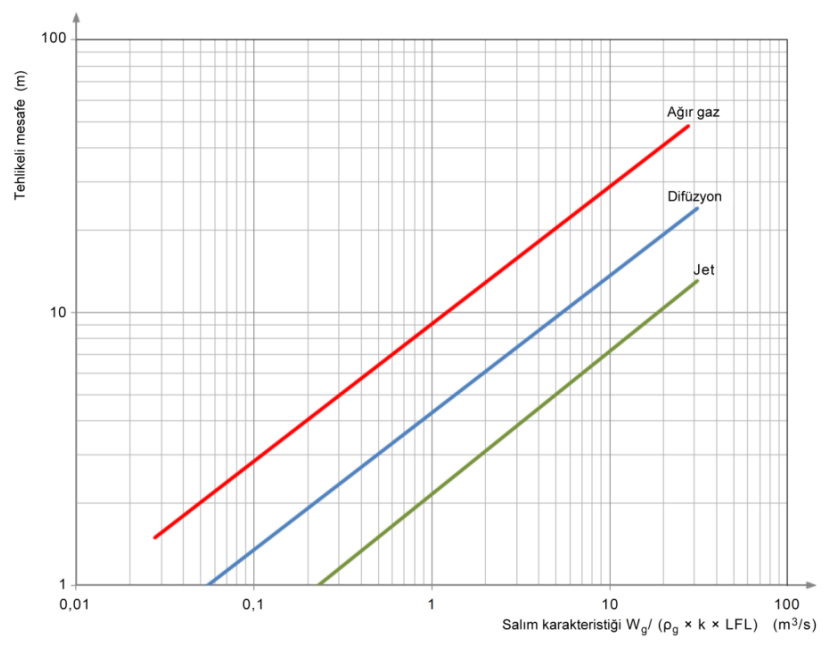

Şekil 2. Tehlikeli alan mesafelerinin tahmini için kullanılan grafik [12]

$\mathrm{Bu}$ grafikte yapılan işlem; salım karakteri değerinin, salım tipi eğrisi ile kesiştiği noktadaki tehlikeli bölgenin mesafesini okumaktır.
Salım kaynă̆ının özellikleri ve ortam şartları dikkate alınarak yapılan değerlendirmelere göre tehlikeli bölgenin silindirik, konik vb. diğer şekillerde olmasına bağlı olarak mesafelerde değişiklikler oluşabilir. Bu değerlendirmeler, değişiklikler ve düzenlemeler, değerlendirmeyi yapan uzman(lar) tarafından yapılır. Tehlikeli bölge şekillerine bir örnek, Şekil.3’te verilmiştir.

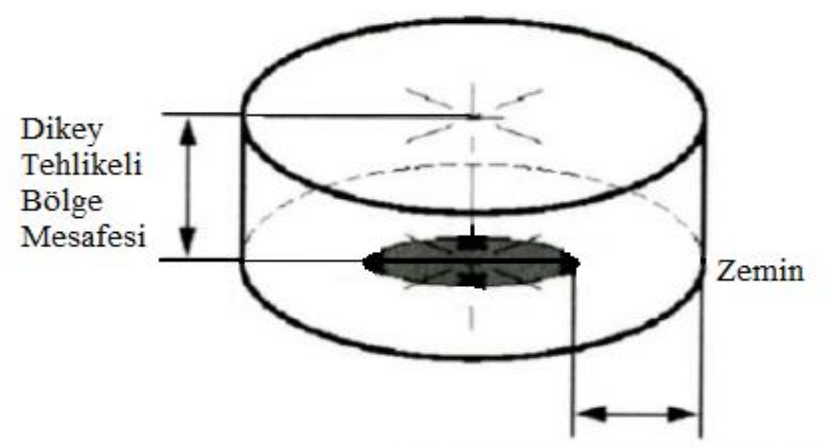

Yatay Tehlikeli Bölge Mesafesi

Şekil 3. Alevlenebilir sıvı (kaynamayan buharlaşma havuzu) [12]

Tutuşabilir tozların oluşturacağ 1 tehlikeli bölgelerin s1nıfları ve salım kaynağı etrafındaki tehlike mesafeleri, en kötü koşullarda yapılan gözlemlere dayanılarak ve toz miktarı, tozun patlayıcılık özellikleri, salım hızı, parçacık boyutları ve tozun nem oranı gibi parametreler göz önüne alınarak değerlendirilebilir. Tabaka, tortu veya yığın halinde tutuşabilir tozların bulunduğu yerler, patlayıcı ortam oluşturabilecek diğer bir salım kaynağı olarak dikkate alınmalıdır [4].

\section{III.BULGULAR ve TARTIŞMA}

\subsection{Hayali Tesisin Tanıtımı}

Örnek olarak, Marmara Bölgesi'nde kurulu bir ambalaj bask1 tesisindeki ambalaj filmi üretim prosesini ve solvent depolama tanklarını inceleyeceğiz. Hayali tesiste, mürekkep solventi olarak kullanılan etil asetat, sıkça ve bol miktarda kullanıldığından dolayı bina dışında kurulu 20 ton'luk çelik depolama tanklarında saklanmakta ve burada kurulu mekanik salmastralı bir pompa ile işletme içerisine pompalanmaktadır. Özellikle pompa veya kompresör gibi yüksek devirle çalışan ekipmanlarla yanıcı madde aktarımı yapılırken kaçaklar oluşması beklenebilir. Tesiste ayrıca, ambalaj filmi üretimi için, toz halde polivinil klorür (PVC) kullanılmaktadır. PVC tozu taneciklerinin en az \%90'ının çapı 0,063 $\mathrm{mm}$ ila $0,25 \mathrm{~mm}$ arasındadır. PVC film hammaddelerinin kontrolleri yapıldıktan sonra mikserlere verilerek karıştırılır. Mikserlere toz hammadde aktarımı, emişli havalandırma 
sistemine sahip besleme hunileri aracılığı ile yapılmaktadır. Aktarım işlemi yapılırken emiş yapan havalandırma sistemi her zaman açık tutulmaktadır ve emiş etkinliğinin iyi olduğu bilinmektedir. Çuvallar bıçakla kesilerek elle boşaltılmaktadır. Karıştırma sırasında ilave yardımcı maddeler eklendikten sonra, üretim yapılacak makinenin ekstrüderine verilerek işlenmeye başlar. Ekstrüderlerin yüzey sıcaklıkları 50 $-170{ }^{\circ} \mathrm{C}$ arasındadır. Bu sicaklık, bölümde bulunan PVC tozunun tutuşma sıcaklığı olan $450^{\circ} \mathrm{C}$ 'nin çok altındadır.

\subsection{Uygulama ve Bulgular}

Hayali tesisimizde inceleyeceğimiz 2 bölüm için, mevcut durumdaki veya olası en kötü senaryolarda oluşabilecek patlayıcı ortamları aşağıda ayrı ayrı inceleyeceğiz.

Değerlendirme 1 - Solvent tanklarının iç hacminde sürekli olarak yüksek miktarda solvent buharı bulunacaktır. Buhar konsantrasyonunun üst patlama limitini aşması beklenebilir, ancak tanka dolum, boşaltım vb. tutuşma riski yüksek operasyonlar esnasında patlayıcı ortam oluşmasını sağlayacak miktarda hava girişi ile mümkün olduğundan, tankların tüm iç hacimleri Bölge 0 olarak sınıflandırılır.

Değerlendirme 2 - Depolama tanklarından etil asetat iletimi için kullanılan pompalardan olası kaçakların oluşturabileceği patlayıcı ortamlar değerlendirilecektir.

Hesaplama için kullanılacak veri ve kabuller şöyledir:

- Tesiste olası en kötü koşullar için en yüksek atmosferik sicaklık $\mathrm{T}_{\mathrm{a}}=40^{\circ} \mathrm{C}=312 \mathrm{~K}$

- Atmosferik basınç $\mathrm{p}_{\mathrm{a}}=101.325 \mathrm{~Pa}$

- TS EN 60079-10-1 standardındaki B.1 çizelgesi kullanılarak, pompa salmastrasından olası kaçağın yüzey alanı $\mathrm{S}=5 \mathrm{~mm}^{2}$

- Pompaların max basıncı yaklaşık 10 bar $=\Delta \mathrm{p}=$ 1.000.000 Pa.

- Etil asetatın alt patlama limiti LFL $=\% 2=0,02$ [3]

- Olası kaçağın şekli belirsiz olacağından, standarttaki örneklere uygun olarak $C_{d}=0,75$

- Etil asetat molekül ağırlı̆̆ $\mathrm{M}=88,11 \mathrm{~kg} / \mathrm{kmol}$, sıv1 yoğunluğu $\rho=900 \mathrm{~kg} / \mathrm{m}^{3}$

- TS EN 60079-10-1 standardındaki C.1 çizelgesi kullanılarak, rüzgar hızı $\mathrm{u}_{\mathrm{w}}=0,3 \mathrm{~m} / \mathrm{sn}$

- Etil asetatın LFL değeri sabittir, ancak olas1 konsantrasyon dalgalanmaları LFL değerine de küçük bir etki edebileceğinden $\mathrm{k}=0,9$

- Tablo 4, Formül No:3 kullanılarak yapılan işlem sonucu, buhar yoğunluğu $\rho_{\mathrm{g}}=3,43 \mathrm{~kg} / \mathrm{m}^{3}$
Hesaplamalar: (Sıvı kaçağı - İkincil Salım) Tablo 4, Formül No:1 kullanılarak yapılan işlem sonucu, kaçan sıvının kütlesel debisi ' $\mathrm{W}=0,16 \mathrm{~kg} / \mathrm{sn}$ '

4 farklı buhar oluşum senaryosu denenecektir:

1 - Kaçan solventin \%100'ünün, sıvı salım hızıyla aynı hızda yanıcı bileşen olarak buharlaştığı varsayılırsa, bu kaçağın yanıcı buhar salım hızı: $\mathrm{Wg}=1,6 \times 10^{-1} \mathrm{~kg} / \mathrm{sn}$

Tablo 4, Formül No:4 kullanılarak yapılan işlem sonucu, salım karakteristiği ' $\mathrm{SK}=2,6 \mathrm{~m}^{3} / \mathrm{sn}$ '

Hesaplama sonucunda elde edilen veriler, Şekil 1'de gösterilen grafiğe yerleştirilir. Bu adım Şekil 4'de çizilerek gösterilmiştir. Görüldüğü gibi bu elde edilen veriler sonucu seyrelme derecesi Orta bulunmuştur.

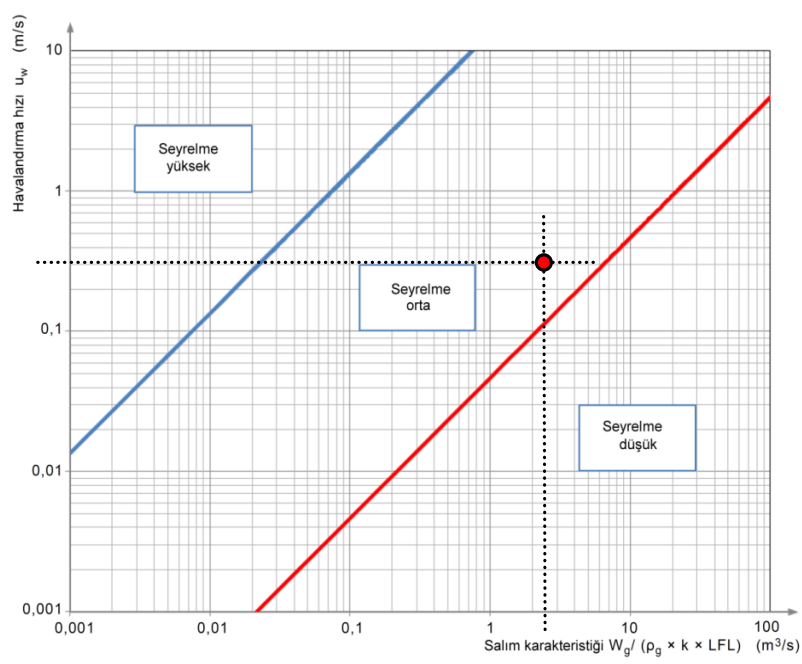

Şekil 4. Seyrelme derecesinin tespiti

Salım kaynağı kaçak ihtimali olduğundan ikincil salım derecesine sahip olduğu ve havalandırma emre amadeliğinin ise Vasat olduğu değerlendirilmiştir. Bu değerlendirmeler Tablo 6 üzerinde kullanılarak patlayıcı atmosfer sınıfinın Bölge 2 olduğu tespit edilmiştir. Bu adım Tablo 7 üzerinde oklarla gösterilmiştir.

Etil asetat buharı havadan yoğundur, ancak senaryomuzdaki şekliyle kaçan sıvının \%100'ünün buharlaşması yüksek hızda püskürmeye işaret ettiğinden, salım tipinin "jet" olmasa bile difüzyonla yayılım olarak değerlendirilmesi gerçeğe daha yakın olacaktır. SK değeri ve salım tipi, Şekil 2'de gösterilen grafiğe yerleştirildiğinde, Bölge 2 olarak sınıflandırılmış olan tehlikeli bölgenin mesafesi 7 metre okunmaktadır. Bu adım Şekil 5'de çizilerek gösterilmiştir. Etil asetat buharının havaya göre yoğunluğu yaklaşık 3'tür ancak ağır gaz yayılımından daha hızlı bir salım öngörüldüğünden, pompalardan etrafa doğru 7 metre yarıçapındaki hacmin Bölge 2 olarak sınıflandırılması gerektiği değerlendirilebilir. 


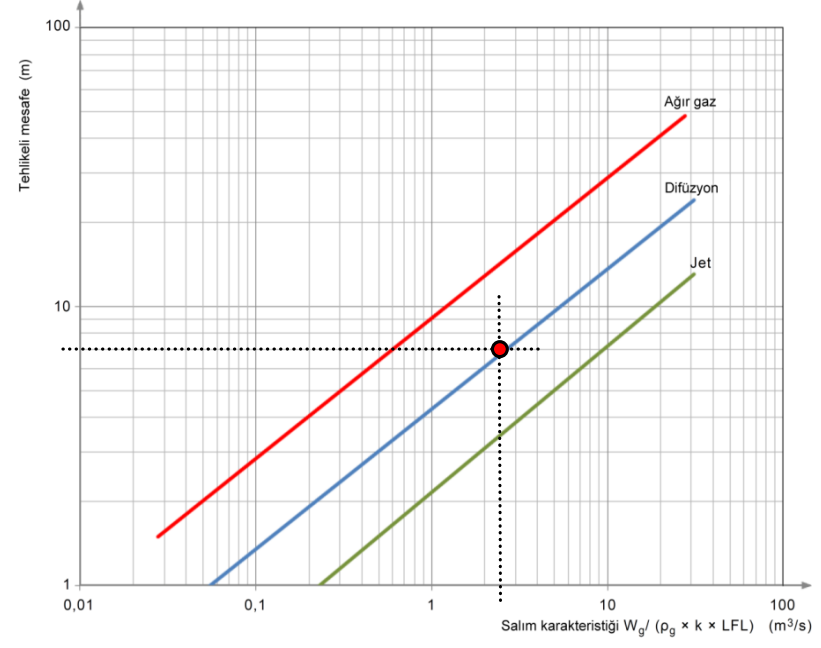

Şekil 5. Tehlikeli bölgenin mesafesinin tespiti

2 - Kaçan solventin \%20'sinin yanıcı bileşen olarak buharlaştı̆̆ varsayılırsa, bu kaçağın yanıcı buhar salım hızı: $\mathrm{W}_{\mathrm{g}}=3,2 \times 10^{-2} \mathrm{~kg} / \mathrm{sn}$

Tablo 4, Formül No:4 kullanılarak yapılan işlem sonucu, salım karakteristiği ' $\mathrm{SK}=0,5 \mathrm{~m}^{3} / \mathrm{sn}$ '

Hesaplama sonucunda Şekil 1. kullanılarak seyrelme derecesi Orta bulunmuştur. Salım kaynağı kaçak ihtimali olduğundan ikincil salım derecesine sahip olduğu ve havalandırma emre amadeliğinin ise Vasat olduğu değerlendirilmiştir. Tablo 5. kullanılarak kaçak ihtimalinin Bölge 2 oluşturduğu tespit edilmiştir. Etil asetat buharı havadan ağırdır ve senaryomuzdaki şekliyle kaçan sıvının \%20'sinin buharlaşması, orta-düşük hızda püskürmeye işaret ettiğinden, salım tipinin ağır gaz salımı olarak değerlendirilmesi uygun bulunmuştur.

Şekil 2.'ye göre, Bölge 2 olarak sinıflandırılmış olan tehlikeli bölgenin mesafesi 6,5 metre okunmaktadır. Bu senaryoya göre, pompalardan etrafa doğru 6,5 metre yarıçapındaki alanın, zeminden 2,5 metre yüksekliğe kadar Bölge 2 olarak sınıflandırılması gerektiği değerlendirilebilir.

3 - Pompanın kurulu olduğu yerde, zeminde drenaj kanalı kurulmuş ise, kaçan solventin büyük kısmı ortamdan uzaklaşarak bir atık tankında toplanacaktır. Bu nedenle kaçak bölgesinde etil asetatın yalnızca \%2'sinin yanıcı bileşen olarak buharlaştığı varsayılırsa, kaçağın yanıcı buhar salım hızı: $\mathrm{W}_{\mathrm{g}}=3,2 \times 10^{-3} \mathrm{~kg} / \mathrm{sn}$

Tablo 4, Formül No:4 kullanılarak yapılan işlem sonucu, salım karakteristiği ' $\mathrm{SK}=0,05 \mathrm{~m}^{3} / \mathrm{sn}$ '

Hesaplama sonucunda Şekil 1. kullanılarak seyrelme derecesi Orta bulunmuştur. Salım kaynağı kaçak ihtimali olduğundan ikincil salım derecesine sahip olduğu ve havalandırma emre amadeliğinin ise Vasat olduğu değerlendirilmiştir. Tablo 5. kullanılarak kaçak ihtimalinin Bölge 2 oluşturduğu tespit edilmiştir. Etil asetat buharı havadan ağırdır ve senaryomuzdaki şekliyle kaçan sıvının \%2'sinin buharlaşması, düşük hızda püskürmeye işaret ettiğinden, salım tipinin ağır gaz salımı olarak değerlendirilmesi uygun bulunmuştur.

Şekil 2.'ye göre, Bölge 2 olarak sınıflandırılmış olan tehlikeli bölgenin mesafesi 2 metre okunmaktadır. Bu senaryoya göre, pompalardan etrafa doğru 2 metre yarıçapındaki alanın, zeminden 1 metre yüksekliğe kadar Bölge 2 olarak sınıflandırılması gerektiği değerlendirilebilir.

4 - Kaçağın damlayarak havuz oluşturacağ boyunca kaçağın fark edilmeyeceği varsayılırsa, toplam kaçak miktarı ve hızı hesabı şöyle yapılabilir;

Toplam kaçağın hacmi $=\mathrm{W} \mathrm{x} \mathrm{t} \rho \rho=0,16 \mathrm{~m}^{3}$

$1 \mathrm{~cm}$ derinliğinde havuz oluşacağ 1 varsayılarak, buharlaşma yüzey alanı $\mathrm{A}_{\mathrm{p}}=16 \mathrm{~m}^{2}$

Tesisin bulunduğu coğrafyada, en sıcak aylarda olası en yüksek sıcaklıklar olan yaklaşık $40^{\circ} \mathrm{C}^{\prime}$ de etil asetatın buhar basinc1 $\mathrm{P}_{\mathrm{v}}=25,1 \mathrm{kPa}$ 'dır.

Tablo 4, Formül No:2 kullanılarak yapılan işlem sonucu, damlama sonucu oluşan havuzdan gerçekleşecek buharlaşma hızı $\mathrm{W}_{\mathrm{e}}=\mathrm{W}_{\mathrm{g}}=7,8 \times 10^{-3} \mathrm{~kg} / \mathrm{sn}$

Tablo 4, Formül No:4 kullanılarak yapılan işlem sonucu, salım karakteristiği 'SK $=0,13 \mathrm{~m}^{3} / \mathrm{sn}$ '

Hesaplama sonucunda Şekil 1. kullanılarak seyrelme derecesi Orta bulunmuştur. Salım kaynağı kaçak ihtimali olduğundan ikincil salım derecesine sahip olduğu ve havalandırma emre amadeliğinin ise Vasat olduğu değerlendirilmiştir. Tablo 5. kullanılarak kaçak ihtimalinin Bölge 2 oluşturduğu tespit edilmiştir. Etil asetat buharı havadan ağırdır ve senaryomuzdaki şekliyle kendiliğinden buharlaşmanın salım tipi ağır gaz salımıdır. Şekil 2.'ye göre, Bölge 2 olarak sınıflandırılmış olan tehlikeli bölgenin mesafesi 3,5 metre okunmaktadır. Pompanın altında oluşacak $16 \mathrm{~m}^{2}$ 'lik etil asetat havuzunun kenarlarından (yaklaş1k 2,5 metre yarıçapında havuz) itibaren etrafa doğru 3,5 metre yarıçapındaki alan tehlikeli bölge olacaktır. Buna göre, toplamda pompanın etrafında 6 metre yarıçapındaki alanın, zeminden 2,5 metre yüksekliğe kadar Bölge 2 olarak sinıflandırılması gerektiği değerlendirilebilir.

Kurulmuş olan 4 senaryonun tümünde, olası patlayıcı atmosfer Bölge 2 olarak sınıflandırılmış, senaryoların çoğunluğunda bu tehlikeli bölgenin yaklaşık 7 metre mesafede ve zeminden 2,5 metre yükseklikte olduğu değerlendirilmiştir. 
Değerlendirme 3 - PVC tozunun patlayıcı ortam oluşturabildiği bilindiğinden, besleme hunilerine dökülmesi esnasında oluşabilecek patlayıcı toz atmosferi değerlendirilecektir.

PVC tozu üreticilerinin teknik ve güvenlik bilgi formlarına göre, tesiste kullanılabilecek PVC tozu taneciklerinin en az \%90'ının çapı $0,063 \mathrm{~mm}$ ila $0,25 \mathrm{~mm}$ arasındadır. PVC tozu için doğrudan veri bulunamamış, ancak yüksek konsantrasyonda PVC içeren emülsiyonlar için bulunan verilere göre, tozun alt patlama limitinin $125 \mathrm{~g} / \mathrm{m}^{3}, \mathrm{dP} / \mathrm{dt}$ değerinin, dolayısıyla patlayıcılık özelliğininse düşük olduğu görülmektedir [13].

Besleme hunisinin ve toz emişi yapan havalandırma sisteminin içleri, tozun doğrudan boşaltıldığı ve aktarıldığı hacimler olduğundan, bu hacimler Bölge 20 olarak sinıfland1rilmalidır.

Etkin havalandırma sistemi bulunmasından dolay1, normal çalışma koşullarında, besleme hunisinin etrafına toz yayılımı beklenmez. Ancak bazen insan hataları sonucu havalandırmanın etkin bölgesinden dışarıda boşaltım yapılabileceği veya havalandırma sisteminde hız/verim düşmeleri gerçekleşebileceği göz önüne alınarak, huninin etrafında belli bir alan Bölge 22 olarak sinıflandırılmalıdır. Tesiste kullanılan PVC tozunun patlayıcılık özelliklerinin zayıf olduğu değerlendirmesine dayanarak, tehlikeli bölgenin mesafesinin1 metreyi aşmasının beklenmediği değerlendirilebilir. Dolayısıyla huninin etrafinda 1 metre yarıçapındaki küresel hacim Bölge 22 olarak sinıflandırılır. Bu sinıflandırmanın tipik çizimi Şekil.6' da verilmiştir.

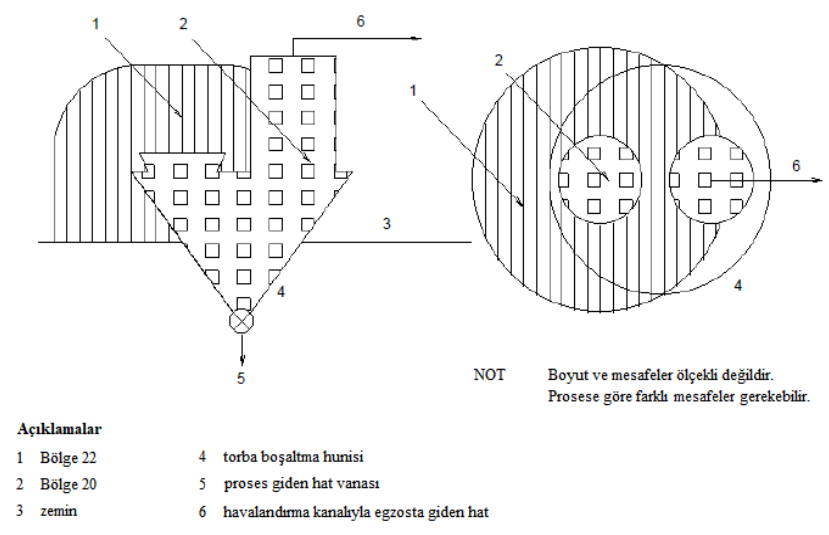

Şekil 6. Emiş (egzoz) havalandırması olan torba boşaltma istasyonu [4]

\subsection{Mevcut ve/veya alınması gereken önlemler}

Genel olarak tüm patlayıcı ortam riski bulunan yerler için mevcut veya alınması gereken birincil önlemleri aşağıdaki gibi sıralayabiliriz.

- Metal olan tüm tanklar, besleme hunileri, aktarım hatları ve makineler uygun ve yeterli şekilde topraklanmış olmalıdır.

- Tehlikeli bölgelere, kolayca okunur ve fark edilir şekilde "Ex Patlayıcı Ortam" ve "Ateşle Yaklaşma" gibi uyarı ve yasaklama işaretleri yerleştirilmelidir [1].

- Tehlikeli bölgelere giriş için yalnızca ilgili bölgelerde patlamadan korunma hususunda özel eğitim almış ve yetkilendirilmiş personele izin verilmeli, bu personele \%100 pamuklu veya anti-statik özellikte tekstil malzemelerinden yapılmış, statik elektrik oluşumunu en az seviyeye indirecek iş kıyafetleri ve anti-statik iş ayakkabıları sağlanmalıdır [1].

- Kesme, kaynak, taşlama veya diğer sıcak çalışmalar, atölye dışında yapılacaksa, yetkili bir idari personel tarafından imzalı şekilde en az aşağıdaki bilgileri içeren çalışma izni formları uygulanmalıdır:

o Yapılacak işin tanımı

o Yapılacak işin süresi ve tarihi

o İşin yapılacağı yer

o İşten önce ve sonra ortamın nasıl güvenlik altına alınacağ 1

o İş esnasında karşılaşılabilecek tutuşturma kaynakları ve bunların nasıl önleneceği

o İşi yapacak ve kontrol edecek kişilerin isimleri

- Sıcak çalışmalar esnasında gerekli minimum güvenlik önlemleri şöyledir:

o Uygun tip, boyut ve miktarda yangın söndürücü(ler) yakında olacaktır

o Zemin veya etraf temizlenecek ve işlem süresince sslak tutulacaktır

o Ex-proof olmayan fan ve diğer emici/üfleyici ekipmanlar kapalı tutulacaktır

o Tüm yanıcı malzemeler en az 11 metre uzaklaştırılacak veya 1sıya/yanmaya dayanıklı bir koruyucu perde/ levha arkasına konulacaktır.

o Duvardaki ve zemindeki açıklıklar kapatılacaktır.

- Sıcak çalışma sonrasında alınacak güvenlik tedbirleri ise şöyledir:

o Yangın izleme; Kesme ve kaynak alanı, uygulanabilir olan yerlerde zeminin altı ve üst kısımları dahi 60 dakika boyunca gezilerek izlenecektir. Bina yanmaz 
yapıdaysa, tüm yanıcı malzemeler en az 11 metre uzağa taşındıysa veya kablo, motor vb. kıvılcım kaynağı ortamda yoksa bu süre 30 dakikaya düşürülebilir

o Yangın gözlemleme; İzleme zamanı dolunca, 3 saate kadar olan bir süre ek bir gözlem yapılacaktır. $\mathrm{Bu}$ gözlem, şunlardan bir veya birkaçı ile yapılabilir; Otomatik duman detektörü, video kamera, rutin emniyet/bakım turları, sahadaki fabrika çalışanları, denetimler (iki denetim arası 20 dakikayı geçmeyecek)

Solvent tankları ve solvent pompası ile ilgili olarak mevcut veya alınması gereken birincil önlemleri aşağıdaki gibi siralayabiliriz.

\section{Patlayıcı ortam oluşmasını önlemek için;}

- Etil asetat vb. yanıcı bir solvent kullanımından vazgeçilerek su bazlı mürekkep kullanımına geçilebilirse, risk tamamen bertaraf edilmiş olacaktır. Bu mümkün olmazsa;

- Solvent aktarımı için, manyetik tahrikli(salmastrasız), sızdırmaz halkalı salmastralı, kutulu vb. "dayanıklı geçirimsizlik" özelliğine sahip bir pompa kullanılması, kaçak riskini ihmal edilebilir seviyeye düşürerek pompa kaynaklı tehlikeli bölgeyi tamamen bertaraf edecektir. Ancak flanşlar, nefeslikler vb. diğer salım/ kaçak kaynakları değerlendirilmelidir. Bu uygulama da mümkün olmazsa;

- Pompanın çok daha iyi havalandırılmış bir noktaya kurulması, tehlikeli bölgenin sınıfinı düşürebilir. Örneğin dış ortamda, pompa zeminden ne kadar yükseğe kurulursa, hava akış hızı o kadar yüksek olacaktır. (Bu değerlendirme için 60079-10-1:2015 standardındaki hava akış hızı tablosu temel alınmıştır.)

\section{Patlayıcı ortamın tutuşmasını önlemek için;}

- Pompanın ex-proof özellikte olması, ekipman kategorisinin en az "Ex II 3G" olmas1 ve etil asetatın kendiliğinden tutuşma sıcaklığı $470^{\circ} \mathrm{C}$ ve gaz sınıfı IIA olduğundan, ekipmanın en az "IIA, T1" özelliklerine sahip olması gerekmektedir.

- Depolama tankları ve pompa topraklanmalı, topraklama direnci periyodik olarak en geç yılda 1 defa ölçülerek ortalama 1 ohm'dan düşük olması sağlanmalıdır. İletkenliği düşük olan başka yanıcı sıvılar depolanıyorsa, bu tür sıvıların statik elektrik oluşturma potansiyeli daha yüksek olduğundan, topraklama direnci sınırı buna uygun olarak daha düşük belirlenebilir.

- Pompa, flanş vb. kaçak olabilecek kritik noktaların yakınına, acil durumda otomatik olarak uyaran ve sistemi güvenli bir duruma getiren (vanaları kapatan, alarm sinyali veren vb.) gaz detektörleri yerleştirilmesi düşünülebilir.

\section{Patlama etkilerini azaltmak için;}

- Tankların içerisine, patlama sensörlü ve hızlı tepki veren patlama bastırma sistemi kurulmas 1 düşünülebilir.

- Tanklara, olası bir patlamanın basıncını düşük riskli bir alana yöneltmek üzere "patlama tahliye kapakları" veya "basınç emniyet valfleri" (pressure relief valve) tesis edilmesi düşünülebilir.

- Tankların altında, olası patlama sonrası gerçekleşebilecek daha büyük sızıntı ve dökülmelerin uzaklara yayılmasını önlemek için bir set/bent görevi görecek şekilde, yanmaya karşı dayanıklı bir havuz tesis edilmelidir.

- Tank sahasına girişin sınırlandırılması, yetkisi olmayanların girişini önlemek için kapısı kilitli tutulan tel çitlerle çevrilmesi düşünülebilir.

Toz besleme hunileri ile ilgili olarak mevcut veya alınması gereken birincil önlemleri aşağıdaki gibi sıralayabiliriz:

\section{Patlayıcı ortam oluşmasını önlemek için;}

- Toz hammadde yerine tamamen granül veya kalın parçacıklı diğer formlarda hammadde temin edilmesi halinde patlayıcı ortam riski tamamen bertaraf edilmiş olacaktır. Teknik olarak mümkünse bu yöntem uygulanmalıdır.

\section{Patlayıcı ortamın tutuşmasını önlemek için;}

- Toz emiş fanının ex-proof özellikte olması, ekipman kategorisinin en az "Ex II 1D" olması ve PVC'nin minimum tutuşma sıcaklığı $220^{\circ} \mathrm{C}$ ve toz sinıfı IIIB olduğundan, ekipmanın en az "IIIB, $\mathrm{T} 145^{\circ} \mathrm{C}$ " özelliklerine sahip olması gerekmektedir. 
Patlama etkilerini azaltmak için;

- Havalandırma kanallarının içerisine, patlama sensörlü ve hızlı tepki veren patlama bastırma sistemi kurulması düşünülebilir.

- Havalandırma kanallarında uygun noktalara, olası bir patlamanın basıncını düşük riskli bir alana yöneltmek üzere "patlama tahliye kapakları" veya "basınç emniyet valfleri" (pressure relief valve) tesis edilmesi düşünülebilir.

\subsection{Tartış̧ma}

Etil asetatın normal ortam şartlarında kaynamamasından dolayı (kaynama sıcaklığı: $77^{\circ} \mathrm{C}$ ) kaçağın buharlaşma hızının, 2. değerlendirme - 1. senaryodaki gibi sıvı kaçağı hızıyla aynı olma ihtimalinin oldukça düşük olduğu düşünülebilir. Ya da 1. Senaryodaki püskürmenin "difüzyonla yayılma" şeklinde değil, "ağır gaz yayılımı" şeklinde gerçekleşeceği yorumlansayd,, tehlikeli bölgenin mesafesi 7 metre değil, 15 metre olacağı değerlendirilebilirdi. Bu yorumlamalar için deneysel veriler kullanılabilse, sonuçlar daha güvenilir olacaktır.

Etil asetat pompasından gerçekleşecek bir kaçağın püskürme/damlama biçimine ve çalışmayı yapan uzmanın yorumlarına bağlı olarak kurulan senaryoların, TS EN 60079-10-1 standardına göre yapılacak tehlikeli bölge değerlendirmelerine etkisinin yüksek olduğu görülmektedir. Bu nedenle, özellikle sıvı kaçakları ile ilgili olarak deneysel çalışmalar yapılarak sektörün faydalanabileceği şekilde yayınlanması, uzman yorumlarının hatalarını azaltmada etkili olacaktır.

Hayali tesiste kullanılan PVC tozunun patlayıcılık özelliklerinin tespiti için TS EN 14034 serisine uygun olarak yapılması gereken testleri yapabilecek akredite laboratuvar Türkiye'de bulunmamaktadır. Bu nedenle endüstride yapılan patlayıcı toz ortamı değerlendirmelerinin büyük kısmı, ancak literatür kaynaklardan edinilen bilgilerle yapılabilmektedir. Bu konuda Türkiye'de akredite test laboratuvarlarının kurulması, endüstrideki toz patlaması değerlendirmelerinde daha güvenilir sonuçlar elde edilmesine yardımcı olacaktır.

Depolama tankları, aktarım boru hatları, farklı iletkenliğe sahip yanıcı sıvılar vb. farklı statik elektrik kaynakları için gerekli topraklama direnci limitlerine dair literatürde kaynak bulmak oldukça güç olduğundan, bu konuda akademik çalışmalar yapılması, kimya endüstrisi için faydalı olacaktır.

\subsection{Sonuç}

İşyerlerindeki patlama ve yangın riskleri; yanıcı ve patlayıcı ortamların oluşmasını veya tutuşmasını önleyecek tedbirleri alarak veya bunlar yeterli olmazsa, patlamanın zararlı etkilerini azaltacak tedbirleri alarak azaltılabilir. Oluşma ihtimali tamamen ortadan kaldırılamayan tehlikeli bölgeler, ilgili mevzuat ve standartlara uygun olarak siniflandirılır ve bu bölgelerde kullanılacak elektrikli ekipmanlar veya tahrikli cihazlar; patlamaya karşı korunmuş tip (Ex-proof) olmalıdır. İlgili TSE standartları temel alınarak yapılabilen tehlikeli bölge sınıflandırma metotlarının bir kısmını, hayali vaka çalışmamızda inceledik ve alınması gerekebilecek tedbirlerle ilgili birçok örnek verdik. Patlama ve yangınların önlenmesi ile ilgili mevzuat ve standartları tamamen ve doğru bir şekilde anlayarak tesislerine uygulayan işyerlerinde, patlama ve yangın riskleri açısından büyük iyileşme öngörülebilir. Aynı şekilde, Türkiye'de ki işyerlerinden bu mevzuat ve standartlara uygun çalışanlarının sayısı arttıkça, ülkenin patlama ve yangın istatistiklerinde iyileşme beklenecektir. İş sağlığı ve güvenliği ile ilgili resmi kurumların; deneysel veriler üreten akademik çalışmalara ve akredite laboratuvarların kurulmasına destek olması, kılavuz dokümanlar yayınlaması ve standartları güncelleyerek geliştirmesi, kimya endüstrisinin daha emniyetli, dolayısıyla daha güvenilir ve verimli bir hale gelmesi açısından önemlidir.

\section{KAYNAKLAR}

[1] Çalışanların Patlayııı Ortamların Tehlikelerinden Korunması Hakkında Yönetmelik (30.04.2013)

[2] TS EN 1127-1 Patlayıcı ortamlar - Patlamayı önleme ve korunma - Bölüm 1: Temel kavramlar ve metodoloji (2012)

[3] TS EN 60079-20-1 Elektrikli Cihazlar - Patlayıcı Ortamlarda Kullanılan - Bölüm 20-1: Gaz ve Buhar Sınıflandırması İçin Malzeme Karakteristikleri - Deney Metotları ve Veriler (2012)

[4] TS EN 60079-10-2 Explosive atmospheres - Part 10-2: Classification of areas - Explosive dust atmospheres (2015)

[5] TS EN 13463-1 Potansiyel patlayıcı ortamlar için elektrikli olmayan donanımlar - Bölüm 1: Temel yöntem ve kurallar (2010)

[6] NFPA 77 - Recommended Practice on Static Electricity (2014)

[7] Muhtemel Patlayıcı Ortamda Kullanılan Teçhizat ve Koruyucu Sistemler İle İlgili Yönetmelik (2014/34/AB) (30.06.2016)

[8] TS EN 60079-0 Patlayıcı ortamlar - Bölüm 0: Donanım - Genel kurallar (2013)

[9] TS EN 60079-14 Elektrikli cihazlar - Patlayıcı ortamlarda kullanılan - bölüm 14: Elektriksel tesislerin tasarımı, seçimi ve monte edilmesi (2014)

[10] Jérôme TAVEAU, (2014). Application of dust explosion protection systems. Procedia Engineering, 84, 297-305

[11] Maria Mitua, Elisabeth Brandes, Werner Hirsch, (2018). Mitigation effects on the explosion safety characteristic data of ethanol/air mixtures in closed vessel. Process Safety and Environmental Protection, 117, 190-199

[12] TS EN 60079-10-1 Patlayıcı ortamlar - Bölüm 10-1: Alanların siniflandirılması - Patlayıcı gaz ortamları (2015)

[13] http://staubex.ifa.dguv.de/explokomp.aspx?nr=461\&lang=e (18.08.2018) 